\title{
Facts and principles learned at the 31st Annual Williamsburg Conference on Heart Disease
}

\author{
mark A. Peterman, MD, Hassan Farood, MD, and William C. Roberts, MD
}

$\mathrm{T}$ The December 2003 conference on heart disease in Williamsburg, Virginia, was the 31 st such conference to be held in that city and has been directed by one of us (WCR) since it began in 1972. The conference usually attracts about 200 enrollees, most of whom are repeat attendees. The conference provides 19.75 hours of continuing medical education credit, and nearly all of the speakers are nationally and/or internationally recognized. It is one of the longest-running cardiology courses sponsored by the American College of Cardiology. Its unique feature is that each presentation is 90 minutes, which allows most speakers to discuss more than one topic and answer questions.

The proceedings of the December 2002 conference were summarized in the April 2003 issue of Baylor University Medical Center Proceedings, and this issue attempts to summarize the proceedings of the December 2003 conference. We took extensive notes during the latest conference and met on many occasions to reproduce as accurately as possible what was said by the presenters. This year's summary also provides many references to the topics discussed.

\section{VASCULAR BIOLOGY OF CORONARY RISK FACTORS}

Robert A. Vogel, MD

1. Cardiovascular disease and endothelial function. Endothelial cell dysfunction, which is reversible, leads to atherosclerosis. It is worsened by hyperlipidemia, hypertension, diabetes mellitus, obesity, and cigarette smoking. Endothelial cell function declines with age unless high levels of physical activity are maintained; physical activity preserves normal endothelial cell function (1-3). High-fat foods acutely decrease endothelial cell function; eating the average fast-food meal reduces endothelial cell function as much as smoking 2 cigarettes. Endothelial cell dysfunction does not occur when an active nonsmoking patient's LDL cholesterol is $<80 \mathrm{mg} / \mathrm{dL}$, systolic BP is $<120 \mathrm{~mm} \mathrm{Hg}$, and BMI is 20 to 25 $\mathrm{kg} / \mathrm{m}^{2}$. A good marriage, a pet dog, and a good laugh now and then improve endothelial cell function and prolong survival.

2. Cardiovascular disease and obesity. Total mortality begins to increase at a BMI of $25 \mathrm{~kg} / \mathrm{m}^{2}$ in Americans, at $22 \mathrm{~kg} / \mathrm{m}^{2}$ in Indians, and at $23 \mathrm{~kg} / \mathrm{m}^{2}$ in Pacific Islanders (4). Obesity causes cardiovascular disease to occur about 10 years earlier than in individuals of the same age who are of normal weight. Levels of Creactive protein decrease by about $50 \%$ if a person loses 30 pounds (14 kg) (5). An overweight but physically fit person, however, is actually healthier than a lean but physically unfit person.

\begin{tabular}{|c|c|}
\hline \multicolumn{2}{|l|}{ Abbreviations used: } \\
\hline$A C E$, angiotensin-converting enzyme & ICD, implantable cardiac defibrillator \\
\hline ACS, acute coronary syndrome & INR, international normalized ratio \\
\hline $\mathrm{AF}$, atrial fibrillation & LDL, low-density lipoprotein \\
\hline AMI, acute myocardial infarction & LMWH, low-molecular-weight \\
\hline$A R$, aortic regurgitation & heparin \\
\hline ARB, angiotensin receptor blocker & $\mathrm{MR}$, mitral regurgitation \\
\hline AS, aortic stenosis & MRI, magnetic resonance imaging \\
\hline AVR, aortic valve replacement & MS, mitral stenosis \\
\hline $\begin{array}{l}\text { BMI, body mass index } \\
\text { BP, blood pressure }\end{array}$ & $\begin{array}{l}\mathrm{PCl} \text {, percutaneous coronary inter- } \\
\text { vention }\end{array}$ \\
\hline $\begin{array}{l}\text { CABG, coronary artery bypass } \\
\text { grafting }\end{array}$ & $\begin{array}{l}\text { PET, positron emission tomography } \\
\text { SCD, sudden cardiac death }\end{array}$ \\
\hline $\begin{array}{l}C A D \text {, coronary artery disease } \\
C T \text {, computed tomography }\end{array}$ & $\begin{array}{l}\text { SPECT, single photon emission com- } \\
\text { puted tomography }\end{array}$ \\
\hline HDL, high-density lipoprotein & UAP, unstable angina pectoris \\
\hline$H F$, heart failure & UFH, unfractionated heparin \\
\hline
\end{tabular}

3. Cardiovascular disease and lipids. Endothelial cell function is normal when the serum LDL cholesterol is $\leq 60 \mathrm{mg} / \mathrm{dL}$ and is clearly abnormal when the LDL cholesterol is $>100 \mathrm{mg} / \mathrm{dL}$ (6). Atherosclerotic progression can be seen with LDL values as low as $80 \mathrm{mg} / \mathrm{dL}$. Endothelial cell function improves when LDL cholesterol is lowered from 100 to $50 \mathrm{mg} / \mathrm{dL}$. The LDL cholesterol level for a person's last 5 years determines his or her risk of cardiovascular disease. If a 65-year-old person who had a serum LDL cholesterol of $160 \mathrm{mg} / \mathrm{dL}$ from age 30 to age 60 lowered it to $100 \mathrm{mg} / \mathrm{dL}$ from age 60 , he or she would have the same risk as a 65-year-old person who always had an LDL cholesterol of $100 \mathrm{mg} / \mathrm{dL}$ ! Endothelial cell function is significantly influenced by HDL cholesterol; an HDL cholesterol $\geq 85 \mathrm{mg} / \mathrm{dL}$ is best for reversing endothelial dysfunction (7). Patients with low HDL cholesterol levels benefit the most from statin therapy. Atheroma regression, as determined by intravascular ultrasonic imaging, occurs within 6 weeks in patients receiving infusions of recombinant HDL (8).

4. Dietary concepts in cardiovascular disease. The average dress size in France is a 6 and in the USA, 14. The portion sizes in French restaurants are 25\% smaller than those in US restaurants. Calories in snacks are mostly fat and sugar; the average American adult eats $150 \mathrm{kcal} /$ day in snacks. Beverages can also be high-

From the Division of Cardiology, Department of Internal Medicine, and the Baylor Heart and Vascular Institute, Baylor University Medical Center, Dallas, Texas.

Corresponding author: William C. Roberts, MD, Baylor Heart and Vascular Institute, Baylor University Medical Center, 3500 Gaston Avenue, Dallas, Texas 75246. 
calorie foods; the average American adult drinks $400 \mathrm{kcal}$ of soft drinks each day. Never eat between meals or drink sugar! One alcoholic drink a day is good for the heart; the type of beverage (wine, beer, or liquor) makes no difference.

5. Concepts in weight loss. Decreasing dietary intake by 100 $\mathrm{kcal} /$ day results in a 25 - to 50 -pound weight loss over 5 years. Start meals with a beverage, soup, or salad and eat smaller portions of the main course. Eat more slowly and avoid snacking. Be aware of the glycemic index: pasta and grains are better than potatoes and white bread. Physical activity is important in maintaining ideal weight, endothelial cell function, and overall cardiovascular health. Type 2 diabetes can be prevented, with few exceptions, by maintaining ideal body weight throughout adulthood $(9,10)$.

6. Cigarette smoking. With each cigarette, 7 minutes of life are lost! Thus, 20 cigarettes ( 1 pack) shorten life span by 140 minutes. One pack daily for a year shortens life span by 35 days, and that amount over a decade shortens life span by 1 year.

\section{SYSTEMIC HYPERTENSION}

Daniel Levy, MD

1. No specific peak systolic or end-diastolic BP number separates normotension from hypertension. Beginning around $115 / 75 \mathrm{~mm} \mathrm{Hg}$, the risk of cardiovascular disease doubles for each increase of $20 \mathrm{~mm} \mathrm{Hg}$ systolic and $10 \mathrm{~mm} \mathrm{Hg}$ diastolic (11). Thus, $\mathrm{BP}$ is a continuum. The Seventh Report of the Joint National Committee on Prevention, Detection, Evaluation, and Treatment of High Blood Pressure (12) proposed the following definitions of systemic BP (in $\mathrm{mm} \mathrm{Hg}$ ): normal BP, <120/80; prehypertension, 120-139/80-89; stage I hypertension, 140-159/90-99; and stage II hypertension, $>160 / 100$. Thiazide diuretics are considered the first-line agents (13). Most patients require $>2$ drugs to reduce their BP to "prehypertensive" levels. Therapy might best begin with 2 agents simultaneously when the systolic BP is $>160 \mathrm{~mm}$ $\mathrm{Hg}$ or the diastolic pressure $>100 \mathrm{~mm} \mathrm{Hg}$ in nondiabetics or when systolic BP is $>150 \mathrm{~mm} \mathrm{Hg}$ or diastolic $>90 \mathrm{~mm} \mathrm{Hg}$ in patients with diabetes mellitus.

2. Systolic BP increases linearly throughout life, regardless of the starting level. Diastolic BP increases to age 50, is level from age 50 to 60 , and then declines after age 60 years (14). Isolated diastolic hypertension is most common in patients in their 30s and decreases at age 91. Contrary to older teachings, isolated systolic hypertension is not a normal part of aging and does need treatment (14).

3. In patients $>60$ years of age with isolated systolic hypertension (systolic BP $>160 \mathrm{~mm} \mathrm{Hg}$ and diastolic $\mathrm{BP}<90 \mathrm{~mm} \mathrm{Hg}$ ), lowering the systolic BP by about $10 \mathrm{~mm} \mathrm{Hg}$ with medications decreases the incidence of stroke by about $40 \%$, CAD by about $30 \%$, and $\mathrm{HF}$ by about $40 \%(15,16)$.

4. The decreased number of cardiovascular events occurring in hypertensive patients on antihypertensive drugs is due to the BP lowering, irrespective of which drugs provided that lowering. In a recent large trial, a diuretic (chlorthalidone), an ACE inhibitor (lisinopril), and a calcium antagonist (amlodipine) produced similar degrees of BP lowering and similar decreases in cardiovascular events (13).

5. Obstacles to BP control include lack of awareness (only about $70 \%$ of patients are aware of their hypertension), lack of treatment (only about $60 \%$ are treated), and lack of adequate treat- ment (only about 30\% are at BP goal) (17). Despite 5 years of close follow-up in a recent trial, only $67 \%$ of patients achieved their BP goal of $<140 / 90 \mathrm{~mm} \mathrm{Hg}$ (13).

6. Diastolic BP is much easier to control than systolic BP. Only about $70 \%$ of patients aged $<60,50 \%$ of those aged 61 to 75 , and $35 \%$ of those aged $>75$ years have their peak systolic pressures lowered by antihypertensive drugs to $<140 \mathrm{~mm} \mathrm{Hg}$ (17).

7. If systemic hypertension were better controlled or eliminated, the frequency of chronic HF would drop about $50 \%(18,19)$. HF that develops after AMI is of the systolic type; HF that develops in the setting of systemic hypertension not associated with AMI, in contrast, is usually of the diastolic type (20-22). Thus, treating hypertension is one of the best means of preventing chronic HF!

\section{EFFECTIVE LONG-TERM WEIGHT MANAGEMENT AND ITS IMPORTANCE}

John P. Foreyt, PhD

1. Obesity in the USA. Two thirds of Americans are overweight, and half of them are obese. In 1976, 47\% of Americans were overweight or obese; by 1988, 56\%; and by $1999,64 \%$. The average American is 25 pounds $(11 \mathrm{~kg})$ heavier than his or her same-sex great-great-grandparent was at the same age. The average Civil War (1861-1865) soldier was 68 inches $(172 \mathrm{~cm})$ tall and weighed 146 pounds $(66 \mathrm{~kg})$; the average American man today is also 68 inches tall but weighs 171 pounds $(77 \mathrm{~kg})$. We all tend to overestimate our height and underestimate our weight. In the past 10 years, the average American adult has increased fat consumption by $26 \mathrm{~g} /$ day and now consumes about $3400 \mathrm{kcal} /$ day.

2. The metabolic syndrome. Over 50 million and perhaps 75 million Americans meet criteria for the metabolic syndrome, namely three of the following: 1 ) abdominal obesity (waist size $>40$ inches in men or $>35$ inches in women), 2) triglycerides $\geq 150$ $\mathrm{mg} / \mathrm{dL}$, 3) HDL cholesterol $<40 \mathrm{mg} / \mathrm{dL}$ in men or $<50 \mathrm{mg} / \mathrm{dL}$ in women, 4) systemic hypertension ( $\mathrm{BP}>130 / 85 \mathrm{~mm} \mathrm{Hg}$ ), and 5) fasting blood glucose $>110 \mathrm{mg} / \mathrm{dL}$. Weight loss decreases BP and serum LDL cholesterol, triglycerides, insulin, and glucose and increases HDL cholesterol!

3. Weight loss. The key factors in the development of obesity are excessive food portion sizes and lack of exercise (23). The chance of developing diabetes mellitus falls nearly $60 \%$ with a low-fat diet and 150 minutes per week of exercise. It's not fat, protein, or carbohydrates that make people obese; it's calories! Fad diets work, but the weight usually returns because of a lack of lifestyle modification. One simple strategy for effective weight loss is the 100/100 plan: eat 100 fewer kcal/day ( 1 cookie or 3 bites of a hamburger) and increase exercise by $100 \mathrm{kcal} /$ day (walk 20 minutes per day). Strength training works as well as aerobics for weight loss, and multiple short bouts of exercise are as good as a long bout for weight loss. Longer bouts of aerobic exercise, however, are better for cardiovascular fitness.

4. Behavioral strategies for weight loss. The most important strategy is self-monitoring, which includes daily weighing and daily recording of all calories ingested (food diary). The average adult underreports calories consumed by one third and overreports exercise by $50 \%$ ! The second most important is stimulus control: avoid snacking and eating too quickly or too slowly. Third is cognitive restructuring: expectations must be realistic, such as $10 \%$ weight loss (about 20 pounds) as a first goal. The average person wants 
to lose $37 \%$ of body weight; this type of goal is unrealistic. The $100 / 100$ plan is a realistic option that should provide a 20 -pound weight loss in a year. Fourth is stress management: physical activity and relaxation techniques such as meditation can reduce stress and decrease snacking. Fifth is social support: eat healthily and exercise together with family or friends.

5. Medical treatment for obesity. Sibutramine (Meridia), a selective serotonin and norepinephrine reuptake inhibitor, enhances satiety in some patients (24). Orlistat (Xenical) blocks fat absorption in the gut by about $30 \%$. Both of these drugs provide a modest (10-pound) weight loss in most patients but are ineffective at achieving more significant weight loss. Gastric bypass is now the treatment of choice for morbid obesity (BMI $>40 \mathrm{~kg} / \mathrm{m}^{2}$ ).

6. Obesity and the environment. Obesity is a problem of the American "toxic" environment; the problem is fast food, huge portions, and sedentary lifestyle (23). We need to focus on prevention of obesity in the young because once present, obesity is hard to overcome.

\section{DEFINING QUALITY IN MEDICAL TREATMENT}

\section{Robert M. Califf, MD}

1. Elements of quality medical care. Care must be safe, effective, timely, efficient, equitable, and patient-centered. Cardiology presently cannot provide all 6 components.

2. Life expectancy. Women born today in the USA have a mean life expectancy of 85 years and men, 80 years. In contrast, the life expectancy of Americans in 1900 was 47 years. With each passing decade, life expectancy in the USA increases by 2 years. Today, only $10 \%$ of the population is $\geq 65$ years of age, but that amounts to 30 million people. By 2030 , it is predicted that $20 \%$, or 70 million Americans, will be $\geq 65$ years of age (25).

3. Upcoming shortage of cardiologists. Because of the increasing number of older persons, cardiovascular disease will be increasing over the next 10 to 20 years. In the meantime, the proportion of cardiologists to population is decreasing despite a continual increase in demand for cardiovascular services (25).

4. Increasing health care costs. US health care costs in 2000 were $\$ 1.2$ trillion. These costs continue to increase because of expensive technological innovations and increasing demands of patients, despite the efforts of government, employers, and insurance companies to limit costs.

5. Improving quality decision making. Decisions are made in the hippocampus, the area of the brain most influenced by images and emotion. Performance indicators of quality care are now being linked to reimbursement by Medicare. Hospitals' mortality rates correlate to the performance of their physicians on these indicators.

\section{RESULTS OF RECENT TRIALS OF PATIENTS WITH LEFT VENTRICULAR SYSTOLIC DYSFUNCTION AFTER ACUTE MYOCARDIAL INFARCTION} Robert M. Califf, MD

1. Captopril ( $50 \mathrm{mg} 3$ times daily), the most commonly used ACE inhibitor in the world, proved superior to losartan $(50 \mathrm{mg}$ daily) for patients with left ventricular systolic dysfunction after AMI, probably because of inadequate dosing of losartan (OPTIMAAL) (26).

2. Captopril ( 6.25 to $50 \mathrm{mg} 3$ times daily), valsartan (20 to $160 \mathrm{mg}$ twice daily) or both (with aggressive dose up-titration in all groups) were compared prospectively in these patients, and no statistically significant differences in mortality were seen in any of the 3 groups (VALIANT) (27). While cough and angioedema were more common in the captopril group, hypotension and creatinine elevation were more common in the valsartan group. Those in the combination group (captopril and valsartan) had more side effects than either single-drug group without any additional benefits. Surprisingly, only about $50 \%$ of patients with decreased left ventricular systolic function after AMI are actually receiving an ACE inhibitor or ARB.

3. The reason the $A R B$ was equivalent to the $A C E$ inhibitor in VALIANT but not in OPTIMAAL is likely to be the aggressive up-titration of the ARB dose in VALIANT. Using the maximal tolerated dose is important in obtaining the maximal clinical benefit for these patients.

4. Eplerenone (25-50 mg daily), an aldosterone antagonist similar to spironolactone but with fewer side effects, proved superior to placebo in patients with depressed left ventricular ejection fractions after AMI (EPHESUS) (28).

\section{RESULTS OF RECENT TRIALS ON THERAPIES FOR CHRONIC HEART FAILURE}

Robert M. Califf, MD

Candesartan proved superior to placebo for patients with chronic HF who could not tolerate ACE inhibitors (CHARMAlternative) (29). The combination of candesartan and an ACE inhibitor was better than an ACE inhibitor alone, with or without a beta-blocker (CHARM-Added). HF patients with a left ventricular ejection fraction $>40 \%$ tended to do better with candesartan than placebo (CHARM-Preserved). The results of these and other trials are now being adapted into quality indicators to measure physicians' and hospitals' abilities to deliver quality medical care, and these indicators soon will determine reimbursement rates.

\section{MANAGEMENT OF ACUTE CORONARY SYNDROMES}

William E. Boden, MD

1. Medical therapy for ACS. ACS is a term used to refer to UAP and AMI, both ST elevation and non-ST elevation. The ABCDEs of ACS management include the following:

- A: antiplatelet, ACE inhibition, anticoagulation

- B: BP control, beta-blockade

- C: cholesterol control, cigarette cessation

- D: diabetes control, dietary modification

- E: exercise, education

The use of aspirin for UAP decreases additional cardiovascular events in 5 years by nearly $50 \%$ (30). The $81-\mathrm{mg}$ and $325-\mathrm{mg}$ doses appear to be equally effective. UFH added to aspirin in ACS may be beneficial, but in a metaanalysis of 6 studies, the difference was statistically insignificant. Clopidogrel provided a slightly better risk reduction than did aspirin in ACS patients (CAPRIE) (31). Clopidogrel added to aspirin proved better than aspirin alone, and the benefit was not offset by the slight increase in bleeding seen in the combination group (CURE) (32). When given prior to $\mathrm{PCI}$, clopidogrel provided a $30 \%$ relative risk reduction compared with aspirin alone (PCI-CURE) (33). The benefit of clopidogrel was greatest when initiated $>6$ hours before PCI (CREDO) (34). 
LMWH for ACS decreases the frequency of death, AMI, and revascularization better than UFH, and the highest-risk patients derive more benefit than the lower-risk patients (ESSENCE and TIMI 11B trials) (35).

Direct thrombin inhibitors provide a $10 \%$ better risk reduction for death and AMI than UFH (36). For patients having PCI, bivalirudin, another direct thrombin inhibitor, had a slight benefit compared with combined UFH and a glycoprotein IIB/IIIA inhibitor (REPLACE II), the benefit resulting entirely from a decrease in major bleeding with bivalirudin.

The "upstream" administration of a glycoprotein IIB/IIIA inhibitor (tirofiban or eptifibatide but not abciximab) combined with UFH early after onset of the ACS, whether or not PCI was planned, is better than UFH alone (PRISM-PLUS, PURSUIT, GUSTO-IV). The higher-risk patients received more benefit than the lower-risk patients, as did diabetics compared with nondiabetics and those who had PCI vs those who did not. For ACS patients undergoing PCI, the benefit of abciximab has been established in multiple studies (EPIC, EPILOG, CAPTURE, EPISTENT).

2. PCI in ACS. Among men with ST depression or positive troponin during hospitalization for ACS, those allocated to cardiac catheterization early had better outcomes than those treated medically who were later studied in the cardiac catheterization laboratory only if at very high risk or if complications developed. This early invasive strategy was not beneficial in women (FRISCII, TACTICS/TIMI-18, RITA-3).

3. Lipids in ACS: "lower is better." After coronary bypass, patients treated with lovastatin $20 \mathrm{mg} /$ day whose LDL cholesterol was $<90 \mathrm{mg} / \mathrm{dL}$ did better than those with LDL cholesterol levels between 100 and $135 \mathrm{mg} / \mathrm{dL}$. A trial comparing 341 patients with stable angina pectoris randomized to atorvastatin $80 \mathrm{mg}$ (46\% LDL lowering) vs PCI plus "usual care" (18\% LDL lowering) disclosed better outcomes at 6 months in the atorvastatin arm (AVERT). In another trial of patients with ACS comparing atorvastatin $80 \mathrm{mg} /$ day vs placebo, those receiving the atorvastatin had better outcomes at 16 weeks (mean LDL decrease from 124 to $72 \mathrm{mg} / \mathrm{dL}$ ) (MIRACL). In a study of patients after PCI, those treated with fluvastatin $80 \mathrm{mg}$ daily had a $22 \%$ relative risk reduction over placebo-treated patients (LIPS).

In the study comparing simvastatin $40 \mathrm{mg}$ daily to placebo in $>20,000$ high-risk patients, most of whom had had an atherosclerotic event and nearly a third of whom had diabetes mellitus, those with baseline LDL cholesterol levels $<100 \mathrm{mg} / \mathrm{dL}, 100-130$ $\mathrm{mg} / \mathrm{dL}$, and $>130 \mathrm{mg} / \mathrm{dL}$ all had similar outcomes (36\% relative risk reduction in 5 years) (Heart Protection Study). A trial combining simvastatin with niacin demonstrated angiographic regression of plaque with therapy (HATS).

\section{NONINVASIVE ASSESSMENT OF MYOCARDIAL VIABILITY IN PATIENTS WITH CORONARY ARTERY DISEASE AND SEVERE LEFT VENTRICULAR DYSFUNCTION}

\section{George A. Beller, MD}

Left ventricular dysfunction can be due to ischemic causes, namely, scar (healed myocardial infarct), stunning (myocardial dysfunction following transient ischemia), or hibernation (myocardial dysfunction due to chronic ischemia in viable tissue), or to nonischemic causes (e.g., habitual alcoholism, systemic hyper- tension, cardiac valvular disease). The concept of hibernation was popularized by Rahimtoola et al when they demonstrated improvement in the left ventricular ejection fraction after CABG (37). About $60 \%$ of patients with HF from CAD have hibernating myocardium. The purpose of viability assessment is to detect hibernating myocardium in patients with left ventricular dysfunction and identify those who may have improved outcomes after revascularization $(38,39)$.

Viability can be assessed by radionuclide perfusion imaging/ SPECT, PET, dobutamine echocardiography, contrast echocardiography, and MRI (40-60). Of the 2 most common methods, dobutamine echocardiography has a higher specificity while SPECT has a higher sensitivity. SPECT can be performed with thallium-201 or technetium-99m; both have similar positive predictive values (about 0.7 ) and negative predictive values (about 0.8 ). MRI has the unique ability to visualize and quantify myocardial scar by detecting "delayed hyperenhancement." In one study, $55 \%$ of patients with myocardial scar by MRI had normal fluorodeoxyglucose PET scans. The extent of myocardial scar present predicts a patient's response to beta-blockade for HF. Those with larger scars show the least improvement.

Patients with positive viability studies have an $80 \%$ lower mortality rate with revascularization compared with medical management. Patients receiving medical therapy with a negative viability study have a $60 \%$ lower mortality rate than medically treated patients with positive viability studies due to their extensive myocardium at risk. Patients with lower ejection fractions and viable myocardium derive the most benefit from revascularization. In one study, hospital mortality after CABG was higher in patients with low ejection fractions and poor viability $(11 \%)$ than in those with low ejection fractions and good viability $(0 \%)$. Patients with viable myocardium improve their functional class on average from 3 to 1.5 after CABG; patients with nonviable myocardium usually show no improvement in functional class. Adding viability assessment to catheterization and clinical data in deciding whether to pursue revascularization results in improved survival after CABG. Although no large randomized trials exist, current evidence suggests that the extent of viability is the best preoperative predictor of survival after CABG. The STICH trial, currently under way, will provide the first large randomized study on the effect of viability testing on outcomes.

It is important to revascularize hibernating myocardium early. Delays of $>1$ month increase long-term mortality from $5 \%$ to $20 \%$ because over time hibernating myocardium undergoes fibrosis and apoptosis.

Reasons for failure to improve function after revascularization despite a preoperative demonstration of viability include poor revascularization, intra- or postoperative reinfarction, graft occlusion, false-positive viability study, or presence of subendocardial scar (scar $>25 \%$ of the wall's thickness). MRI is the only reliable method for detecting subendocardial scar.

Radionuclide myocardial perfusion imaging in other settings includes detection of CAD, assessment of risk, and determination of the significance of an intermediate coronary narrowing on cardiac catheterization. Exercise is the best form of stress for nuclear studies. An alternative is the "adenowalk," the performance of low levels of exercise during an adenosine infusion. Dobutamine is used in those who cannot exercise or have reactive airways. 
Nuclear imaging looks for an imbalance in perfusion and requires a normal area to detect an abnormal one; if all areas are abnormal, the study may be falsely negative (balanced ischemia). Transient ischemic dilation is an important marker of myocardial ischemia, even without a discrete abnormality, and usually is indicative of 3-vessel CAD with balanced ischemia.

Most patients (85\%) with intermediate Duke's treadmill scores can have their risk clarified with the addition of nuclear imaging. A normal nuclear stress test gives a $1 \%$ risk of AMI or death in the next 4 years. Patients who have positive pharmacologic stress tests are at higher risk than those with positive exercise stress tests because inability to exercise is a risk in itself. In dobutamine nuclear stress tests, a positive electrocardiogram with negative images carried the same risk as a negative electrocardiogram with positive images; having both tests positive indicated the highest risk. A normal nuclear stress test is less reliable in diabetic patients, who have a threefold to fourfold increased risk with a normal study than do nondiabetics ( $0.3 \%$ to $1 \%$ for men, $0.5 \%$ to $2 \%$ for women). Statin therapy can reverse a myocardial ischemic defect on nuclear stress test without revascularization!

\section{CONGESTIVE HEART FAILURE}

Robert O. Bonow, MD

1. Concepts. HF is an increasing problem; 62 million people in the USA have risk factors for HF, and $>5$ million have symptomatic HF (61). In whites HF is usually (65\%) due to CAD, whereas in blacks it is usually due to hypertension. The 2 major goals of HF treatment are to improve hemodynamics and reduce neurohormonal stimulation. Neurohormonal stimulation causes increased oxygen consumption, tachycardia, myocardial hypertrophy, arrhythmias, and myocardial necrosis. The goals in compensated HF are hemodynamic improvement, neurohormonal modulation (beta-blocker, ACE inhibitors, ARBs, and aldosterone antagonists), prevention of left ventricular dilation, and prevention of further coronary narrowing. The goal in decompensated HF is hemodynamic stabilization (avoiding inotropes whenever possible).

2. Management. Proper management of HF requires establishing its cause, determining whether it is mainly systolic or diastolic, correcting the precipitating factors (especially myocardial ischemia if present), initiating therapy, and assessing response. General principles of management include 1) control volume (diuretics); 2) slow disease progression (beta-blockers or ACE inhibitors or ARBs); 3 ) prevent sudden death (beta-blockers or ICDs); and 4) treat symptoms (digoxin or cardiac resynchronization therapy).

ACE inhibition is a cornerstone of HF therapy (62-64). Seven trials have shown these agents to be effective and to decrease the mortality rate (61). Low BP (in the absence of orthostatic symptoms) and elevations of creatinine are not contraindications to ACE inhibitors. ARBs are equivalent to ACE inhibitors and, of course, are the drugs of choice in patients who cannot tolerate ACE inhibitors because of symptoms such as cough or angioedema $(27,29,65)$. Whether the combination of an ARB and an ACE inhibitor offers additional benefit is still unclear. Aldosterone antagonists (spironolactone, eplerenone) also have been demonstrated to have a $30 \%$ relative risk reduction for patients with New York Heart Association class III and IV HF $(66,67)$. The choice of diuretic depends on renal function: loop diuretics should be used twice daily if the creatinine clearance is $<30 \mathrm{~mL} / \mathrm{min}$ and thiazides if it is $>30 \mathrm{~mL} / \mathrm{min}$. Digoxin is useful in both systolic and diastolic HF, but the serum level must be $<1.2 \mathrm{mg} / \mathrm{dL}$ (68). Betablockers can improve ejection fractions in HF patients after 3 to 6 months of therapy (following a small initial decrease). Only metoprolol, carvedilol, and bisoprolol have been approved for use in HF patients (69-71). Doses of these drugs should be titrated slowly over 2-week intervals and usually started in the hospital after the patient has been adequately diuresed. It is not advisable to stop beta-blockers in patients admitted with HF exacerbations, as this may trigger a worsening of symptoms. Low BP (in the absence of orthostasis) and low ejection fraction are not contraindications to beta-blockade in HF. Patients with an ejection fraction $<35 \%$ who are at high risk of SCD should be considered for ICD implantation (72). Patients with class III or IV HF and a wide ( $>0.12$ seconds) QRS complex should be considered for cardiac resynchronization therapy (biventricular pacing).

3. Principles for management of HF with normal systolic function (diastolic HF). 1) Control systolic and diastolic BP. 2) Control ventricular rate in patients with AF. 3) Anticoagulate all patients with AF. 4) Restore sinus rhythm in patients with AF. 5) Control edema with diuretics. 6) Revascularize patients with myocardial ischemia. 7) Prescribe beta-blockers, ACE inhibitors, and/or ARBs. 8) Use digoxin to minimize symptoms.

4. Management of ischemic HF. CAD has long been considered the initiating factor in ischemic HF but has been ignored as a factor in accelerating the decline of HF patients through ongoing myocyte injury $(61,73-75)$. Aggressive CAD treatment strategies (aspirin, ACE inhibitor, beta-blocker, statin) must be applied to HF patients if there is any chance that CAD may be playing a role in their HF (76). ACE inhibition and beta-blockade are most beneficial to patients with both CAD and HF. Patients with HF from CAD (ischemic cardiomyopathy) have worse outcomes than those with nonischemic HF with the same degree of left ventricular dysfunction. Viability assessment and revascularization are key in the treatment of these patients and may slow progression or reverse their $\operatorname{HF}(77,78)$.

\section{DIASTOLIC HEART FAILURE}

\section{A. Jamil Tajik, MD}

1. Definitions. HF is not a disease but a manifestation of a disease. The etiology of HF always needs to be sought. About $80 \%$ of patients $\geq 75$ years of age have some form of left ventricular diastolic dysfunction. Half of patients with HF have diastolic rather than systolic dysfunction, and the survival of patients with these 2 forms of HF is identical (79). Systemic hypertension is by far the leading cause of diastolic HF, with myocardial ischemia a distant second.

2. HF stages. Stage A is the presence of risk factors only (e.g., hypertension); treatment should be directed at modifying the risk factors. Stage B is asymptomatic left ventricular dysfunction; identifying and aggressively treating this stage is crucial to preventing symptomatic HF. Stage $C$ is symptomatic left ventricular dysfunction; at this point the process is irreversible and treatment is difficult. Stage $D$ is terminal HF.

3. Echocardiographic assessment of diastolic HF. The history, physical examination, electrocardiogram, chest radiograph, and laboratory studies are useful in diagnosing HF, but none of these 
can distinguish systolic from diastolic HF; only echocardiography can separate them. Mitral inflow and mitral annular tissue Doppler can be used to assess diastolic dysfunction; the $\mathrm{E}: \mathrm{E}^{\prime}$ ratio is the most sensitive marker (80). Assessment of left atrial volume also can be helpful in diagnosing diastolic HF.

Diastolic dysfunction on echocardiogram is graded I through IV: grade I is impaired relaxation, grade II is pseudonormalization, grade III is restrictive filling without maximal medical therapy, and grade IV is restrictive filling despite maximal medical therapy. Simultaneous Doppler and catheterization studies have shown that grade I diastolic dysfunction equates to a mean left atrial pressure of about $8 \mathrm{~mm} \mathrm{Hg}$ and grade III, to a mean of about $28 \mathrm{~mm} \mathrm{Hg}$. Grade I diastolic dysfunction increases mortality rates eightfold, and grade II/III diastolic dysfunction increases them 20-fold.

4. Echocardiographic maneuvers in assessing diastolic HF. Prognosis and responsiveness to therapy can be predicted in diastolic HF patients by performing echocardiography during a Valsalva maneuver: if the diastolic pattern improves (grade III to grade I or II), then the patient is likely to respond well to volume unloading with diuretics. The contribution of mild (grade I) diastolic HF to a patient's exertional dyspnea can be assessed by performing echocardiography during supine bicycle exercise. If the diastolic pattern worsens (grade I to grade II or III) with exercise, then it is likely that the mean left atrial pressure is increasing to $>25 \mathrm{~mm}$ $\mathrm{Hg}$, and pulmonary edema is the cause of exertional dyspnea.

5. Therapy for diastolic HF. Therapy for diastolic HF is determined primarily by the severity of the dysfunction. Patients with grade I diastolic dysfunction have normal left atrial pressures and are best treated with maintenance of sinus rhythm, slower heart rates, and neurohormonal blockade (beta-blockers, ACE inhibitors, aldosterone antagonists). Patients with grade III diastolic dysfunction have high left atrial pressures and short mitral deceleration times (i.e., left ventricular filling is completed during the first third of ventricular diastole), and decreasing heart rate does not improve left ventricular filling but instead decreases cardiac output. Patients with grade III diastolic dysfunction have tiny awaves (i.e., minimal atrial contribution to left ventricular filling), and they are not necessarily worse off in AF. These patients need gentle diuresis and neurohormonal blockade.

\section{PERICARDIAL DISEASE}

\section{A. Jamil Tajik, MD}

1. Pericardial constriction. The number one cause of constrictive pericardial disease today is prior cardiac surgery (occurring up to 10 years earlier). Any patient not doing well after cardiac surgery should be considered to have pericardial constriction until proven otherwise. The number of cases of constrictive pericardial disease is increasing as awareness and diagnostic tools improve. Thickened pericardia can be seen on CT or MRI, but nearly $20 \%$ of cases have pericardia of normal thickness on these studies. Calcified pericardia are indicative of old or chronic disease, and the prognosis in patients with calcified pericardia is worse than in patients with noncalcified pericardia.

2. Hemodynamic features of constriction. The 2 hallmark features of pericardial constriction in the catheterization laboratory are dissociation between intracavitary (left ventricular) and intrathoracic (pulmonary artery) pressures. To distinguish restrictive cardiomyopathy from pericardial constriction, the superimposed left ventricular and pulmonary artery pressure tracings need to be studied during the respiratory cycle. In restrictive cardiomyopathy, the left ventricular and pulmonary arterial pressure tracings move up and down together with respiration (concordance); in pericardial constriction, in contrast, the left ventricular and pulmonary artery pressure tracings move closer together with inspiration and separate with expiration (discordance).

\section{ECHOCARDIOGRAPHY: PAST, PRESENT, AND FUTURE}

\section{A. Jamil Tajik, MD}

Echocardiography may be the most important breakthrough in cardiology in the past 4 decades! Over 50,000 echocardiograms were done at the Mayo Clinic in 2002. Echocardiography has 2 big advantages over CT and MRI: 1) the ability to image irregular rhythms (no gating) and 2) portability. In the near future, handheld echocardiography will be ubiquitous, the first new bedside diagnostic tool for physicians since the development of noninvasive $\mathrm{BP}$ measurement nearly 100 years ago.

\section{ATRIAL FIBRILLATION}

Harold L. Kennedy, MD

1. Definitions. AF lasting $<7$ days is considered paroxysmal and that lasting $>7$ days, persistent. Cardioversion is more successful in the paroxysmal type than the persistent type. Most patients (70\%) with $\mathrm{AF}$ are $>65$ years of age. Risk factors for $\mathrm{AF}$ include systemic hypertension, diabetes mellitus, HF, and AMI. AF increases mortality rates twofold and the risk of stroke fivefold (81).

2. Principles of treatment (82). 1) Control ventricular rate (with beta-blockade, calcium antagonists, or digoxin). 2) Prevent emboli (aspirin, warfarin, or ximelagatran). 3) Restore sinus rhythm (with antiarrhythmic drugs or direct-current cardioversion). 4) Maintain sinus rhythm (antiarrhythmic drugs, radiofrequency ablation, or pacing). Direct-current cardioversion is more successful with bipolar defibrillators than with unipolar ones. An anteroposterior pad position is preferable to an anterolateral position (83). Use at least $200 \mathrm{~J}$ from the beginning rather than lower energies. In patients with HF, treatment with ACE inhibitors results in a near- $20 \%$ absolute risk reduction for development of AF compared with patients not receiving them.

3. Rate control vs rhythm control. Rate control is slightly more beneficial in persistent $\mathrm{AF}$ than is rhythm control $(84,85)$. If patients with persistent AF are $>65$ years of age or have symptomatic HF, rhythm control may still be useful (AFFIRM). Neither rhythm control nor rate control obviates the need for warfarin in patients with AF.

4. Devices for treatment. Because the pulmonary veins may have "sleeves" of muscle that may produce ectopic electrical foci, isolation of the pulmonary veins with radiofrequency ablation decreases the incidence of AF by $80 \%$ and improves morbidity rates, mortality rates, and quality of life (86-88). This procedure, however, may cause stricture and/or thrombosis of one or more pulmonary veins, a complication that may limit its application.

5. Anticoagulation. The use of aspirin alone is acceptable in low-risk patients, but in high-risk patients warfarin should be used, with a target INR of 2 to 2.5 (SPAF). In a recent trial comparing ximelagatran, a new oral direct thrombin inhibitor, and warfarin, ximelagatran was equivalent to warfarin for stroke prevention and slightly superior for reducing bleeding complica- 
tions (SPORTIF-III) $(89,90)$. Ximelagatran, however, produced increased hepatic transaminase levels in $6 \%$ of the patients.

\section{SUDDEN CARDIAC DEATH}

Harold L. Kennedy, MD

SCD most commonly is the consequence of atherosclerotic CAD but on occasion is the result of other structural cardiac conditions or a primary electrical system disorder (e.g., long QT syndrome) (91, 92). Some investigators suggest that an ICD should be inserted in all patients with aborted SCD. Current American College of Cardiology/American Heart Association guidelines, however, state that an ICD is indicated only if there is no identifiable reversible cause of the SCD. Patients with healed AMI, HF, low ejection fractions, nonsustained ventricular tachycardia (on Holter monitoring), and inducible ventricular tachyarrhythmia on electrophysiologic study (i.e., those at highest risk) have better survival when randomized to ICD placement (MADIT-I, MUSTT) (93-95). A recent trial of patients with ischemic cardiomyopathy, an ejection fraction $<35 \%$, and no electrophysiologic study showed that the patients receiving an ICD had a 30\% decrease in mortality rates after 20 months compared with those receiving only medical therapy, mainly amiodarone (MADIT-II) (72). In patients with ICDs, beta-blockers are useful in preventing frequent firings of the ICD. Mortality rates in patients with idiopathic dilated cardiomyopathy are not improved by prophylactic insertion of an ICD (96).

\section{CARDIOVASCULAR DISEASE AND THE SLEEP APNEA SYNDROME}

Harold L. Kennedy, MD

Sleep apnea is common in patients who are obese, who habitually snore, who are $>65$ years of age, who have neck circumference sizes $>17$ inches $(43 \mathrm{~cm})$, and who have an abnormal pharynx. Apneas and hypopneas at night requiring arousal elevate catecholamine levels and result in hypertension $(97,98)$. Therapy with continuous positive airway pressure can decrease the number of apneas and hypopneas and thus reduce BP. Sleep apnea also increases serum levels of C-reactive protein and interleukin-6, both of which can be lowered by continuous positive airway pressure therapy (99). Sleep apnea affects about 50\% of patients with HF (100).

\section{CURRENT AND FUTURE MANAGEMENT OF VALVULAR HEART DISEASE}

Jeffrey S. Borer, MD

1. AS. Patients with untreated symptomatic AS have an average survival of 2 years. Survival in asymptomatic patients with AS is good and is not improved by AVR. Exercise testing can help determine which asymptomatic (at rest) AS patients would benefit from AVR. (The risk of mortality on the treadmill is extremely low.) Indications for AVR in asymptomatic patients with AS include aortic valve jet velocity $>4.0 \mathrm{~m} / \mathrm{sec}$, jet velocity across the aortic valve that has increased by $>0.3 \mathrm{~m} / \mathrm{sec}$ in a year, abnormal exercise stress test, and low ejection fraction at rest. Calcific deposits on aortic valves detected by echocardiography imply worse outcomes. After AVR, maximal improvement in ejection fraction may take up to 3 years.

2. MS. MS is a long, slowly progressive disease. If the patient is asymptomatic or mildly symptomatic, the survival is $80 \%$ at 10 years. Patients with moderate to severe symptoms, however, have a $<15 \%$ survival at 10 years. Patients with severe pulmonary hypertension have a mean survival of $<3$ years. Mitral valve area can be improved greatly by balloon valvuloplasty. Percutaneous valvuloplasty has equivalent mortality to open commissurotomy with less morbidity.

3. AR. Patients with asymptomatic AR with depressed left ventricular function require AVR. The worse the preoperative left ventricular ejection fraction in patients with $A R$, the worse their survival after AVR. Drug therapy for AR is usually successful only in patients with coexisting systemic hypertension. Longacting nifedipine can reduce the degree of AVR and delay AVR. Although both could potentially decrease the degree of AR, ACE inhibitors and amlodipine have not been tested.

4. MR. Severe MR by itself is not an indication for a mitral operation. Indications for surgery for asymptomatic MR include a depressed left ventricular or right ventricular ejection fraction and severe pulmonary hypertension. Medical therapy infrequently provides much benefit. Mitral valve repair is preferred over replacement in patients with purely regurgitant mitral valves.

\section{SURGICAL THERAPY FOR CORONARY AND VALVULAR HEART DISEASES}

Charles S. Roberts, MD

1. CABG. Nearly $95 \%$ of patients having CABG for angina pectoris are angina-free at 1 year after operation. The mortality risk of CABG is the same as for hip surgery. The patients at highest risk for early mortality after CABG include age $>90$ years, BMI $>40$ or $<22 \mathrm{~kg} / \mathrm{m}^{2}$, AMI in the last 48 hours, and emergent CABG. The outcomes of CABG with cardiopulmonary bypass are equivalent to those done "off-pump" (101). Additionally, off-pump CABG requires "stabilization" of the beating heart and allows poor access to the left circumflex coronary artery and its branches. As a consequence, it is utilized in $<10 \%$ of $\mathrm{CABG}$ operations nationwide.

2. Valvular cardiac surgery. Mechanical valves, the preferred valve in patients without contraindications to anticoagulation, are gaining increasing competition from bovine pericardial bioprostheses. These bioprostheses have improved longevity over the porcine aortic valves and avoid the risk of bleeding from warfarin and emboli associated with mechanical valves. A significant endorsement comes from cardiothoracic surgeons, who tend to request that these bioprostheses be used when valve replacement is needed. Maintaining low cholesterol levels, low BPs, and low heart rates can prolong the life of bioprostheses. The Ross procedure (moving the pulmonic valve to the aortic position) is recommended only if AVR is indicated in a patient $<30$ years old. Mitral valve repair is useful for myxomatous or ischemic MR but rarely in valves damaged by infective or rheumatic heart disease $(102,103)$.

3. Cardiothoracic surgery training. The number and quality of applicants for cardiothoracic surgery training positions have been declining for several years. The widespread use of coronary angioplasty and stenting is decreasing the number of $\mathrm{CABG}$ operations done, while those that are done now involve higher-risk patients. Trainees are increasingly less experienced as a result of this lower volume of procedures. Therefore, the number of trainees annually needs to be decreased to provide an adequate number of procedures for training. 
1. Celermajer DS, Sorensen KE, Spiegelhalter DJ, Georgakopoulos D, Robinson J, Deanfield JE. Aging is associated with endothelial dysfunction in healthy men years before the age-related decline in women. J Am Coll Cardiol 1994;24:471-476.

2. DeSouza CA, Shapiro LF, Clevenger CM, Dinenno FA, Monahan KD, Tanaka H, Seals DR. Regular aerobic exercise prevents and restores agerelated declines in endothelium-dependent vasodilation in healthy men. Circulation 2000;102:1351-1357.

3. Lee I-M, Sesso HD, Paffenbarger RS Jr. Physical activity and coronary heart disease risk in men. Does the duration of exercise episodes predict risk? Circulation 2000;102:981-986.

4. Suwaidi JA, Wright RS, Grill JP, Hensrud DD, Murphy JG, Squires RW, Kopecky SL. Obesity is associated with premature occurrence of acute myocardial infarction. Clin Cardiol 2001;24:542-547.

5. Tchernof A, Nolan A, Sites CK, Ades PA, Poehlman ET. Weight loss reduces $\mathrm{C}$-reactive protein levels in obese postmenopausal women. Circulation 2002;105:564-569.

6. Steinberg HO, Bayazeed B, Hook G, Johnson A, Cronin J, Baron AD. Endothelial dysfunction is associated with cholesterol levels in the high normal range in humans. Circulation 1997;96:3287-3293.

7. Brown BG, Zhao X-Q, Chait A, Fisher LD, Cheung MC, Morse JS, Dowdy AA, Marino EK, Bolson EL, Alupovic P, Frohlich J, Albers JJ. Simvastatin and niacin, antioxidant vitamins, or the combination for the prevention of coronary disease. N Engl J Med 2001;345:1583-1592.

8. Nissen SE, Tsunoda T, Tuzcu EM, Schoenhagen P, Cooper CJ, Yasin M, Eaton GM, Lauer MA, Sheldon WS, Grines CL, Halpern S, Crowe T, Blankenship JC, Kerensky R. Effect of recombinant ApoA-1 Milano on coronary atherosclerosis in patients with acute coronary syndromes. A randomized controlled trial. JAMA 2003;290:2292-2300.

9. Tuomilehto J, Lindström J, Eriksson JG, Valle TT, Hämäläinen H, IlanneParikka P, Keinänen-Kiukaanniemi S, Laakso M, Louheranta A, Rastas M, Salminen V, Uusitupa M; Finnish Diabetes Prevention Study Group. Prevention of type 2 diabetes mellitus by changes in lifestyle among subjects with impaired glucose tolerance. N Engl J Med 2001;344:1343-1350.

10. Knowler WC, Barrett-Connor E, Fowler SE, Hamman RF, Lachin JM, Walker EA, Nathan DM; Diabetes Prevention Program Research Group. Reduction in the incidence of type 2 diabetes with lifestyle intervention or metformin. N Engl J Med 2002;346:393-403.

11. Lewington S, Clarke R, Qizilbash N, Peto R, Collins R; Prospective Studies Collaboration. Age-specific relevance of usual blood pressure to vascular mortality: a meta-analysis of individual data for one million adults in 61 prospective studies. Lancet 2002;360:1903-1913.

12. Jones DW, Hall JE. Seventh report of the Joint National Committee on Prevention, Detection, Evaluation, and Treatment of High Blood Pressure and evidence from new hypertension trials. Hypertension 2004;43:1-3.

13. The ALLHAT Officers and Coordinators for the ALLHAT Collaborative Research Group. Major outcomes in high-risk hypertensive patients randomized to angiotensin-converting enzyme inhibitor or calcium channel blocker vs diuretic. The Antihypertensive and Lipid-Lowering Treatment to Prevent Heart Attack Trial (ALLHAT). JAMA 2002;288:2981-2997.

14. Franklin SS, Gustin W IV, Wong ND, Larson MG, Weber MA, Kannel WB, Levy D. Hemodynamic patterns of age-related changes in blood pressure: The Framingham Heart Study. Circulation 1997;96:308-315.

15. Staessen JA, Fagard R, Lutgarde T, Celis H, Arabidze GG, Birkenhäger WH, Bulpitt CJ, de Leeuw PW, Dollery CT, Fletcher AE, Forette F, Leonetti G, Nachev C, O'Brien ET, Rosenfeld J, Rodicio JL, Tuomilehto J, Zanchetti A; Systolic Hypertension in Europe (Syst-Eur) trial investigators. Randomised double-blind comparison of placebo and active treatment for older patients with isolated systolic hypertension. Lancet 1997;350:757-764.

16. Sagie A, Larson MG, Levy D. The natural history of borderline isolated systolic hypertension. N Engl J Med 1993;329:1912-1917.

17. Lloyd-Jones DM, Evans JC, Larson MG, O'Donnell CJ, Roccella EJ, Levy D. Differential control of systolic and diastolic blood pressure: factors associated with lack of blood pressure control in the community. Hypertension 2000;36:594-599.

18. Levy D, Larson MG, Vasan RS, Kannel WB, Ho KKL. The progression from hypertension to congestive heart failure. JAMA 1996;275:1557-1562.

19. Kostis JB, Davis BR, Cutler J, Grimm RH Jr, Berge KG, Cohen JD, Lacy CR, Perry HM, Jr, Blaufox MD, Wassertheil-Smoller S, Black HR, Schron E,
Berkson DM, Curb JD, Smith WM, McDonald R, Applegate WB. Prevention of heart failure by antihypertensive drug treatment in older persons with isolated systolic hypertension. SHEP Cooperative Research Group. JAMA 1997;278:212-216.

20. Vasan RS, Larson MG, Benjamin EJ, Evans JC, Reiss CK, Levy D. Congestive heart failure in subjects with normal versus reduced left ventricular ejection fraction. Prevalence and mortality in a population-based cohort. J Am Coll Cardiol 1999;33:1948-1955.

21. Vasan RS, Levy D. Defining diastolic heart failure. A call for standardized diagnostic criteria. Circulation 2000;101:2118-2121.

22. Zile MR, Gaasch WH, Carroll JD, Feldman MD, Aurigemma GP, Schaer GL, Ghali JK, Liebson PR. Heart failure with a normal ejection fraction. Is measurement of diastolic function necessary to make the diagnosis of diastolic heart failure? Circulation 2001;104:779-782.

23. Poston WSC II, Foreyt JP. Obesity is an environmental issue. Atherosclerosis 1999;146:201-209.

24. James WPT, Astrup A, Finer N, Hilsted J, Kopelman P, Rössner S, Saris WHM, Van Gaal LF; STORM Study Group. Effect of sibutramine on weight maintenance after weight loss: a randomised trial. Lancet 2000;356:2119-2125.

25. Foot DK, Lewis RP, Pearson TA, Beller GA. Demographics and cardiology, 1950-2050. J Am Coll Cardiol 2000;35:1067-1081.

26. Dickstein K, Kjekshus J; OPTIMAAL Study Group. Effects of losartan and captopril on mortality and morbidity in high-risk patients after acute myocardial infarction: the OPTIMAAL randomised trial. Lancet 2002;360: $752-760$.

27. Pfeffer MA, McMurray JJV, Velazquez EJ, Rouleau J-L, Køber L, Maggioni AP, Solomon SD, Swedberg K, Van de Werf F, White H, Leimberger JD, Henis M, Edwards S, Zelenkofske S, Sellers MA, Califf RM; Valsartan in Acute Myocardial Infarction trial investigators. Valsartan, captopril, or both in myocardial infarction complicated by heart failure, left ventricular dysfunction, or both. N Engl J Med 2003;349:1893-1906.

28. Spertus JA, Tooley J, Jones P, Poston C, Mahoney E, Deedwania P, Hurley S, Pitt B, Weintraub WS. Expanding the outcomes in clinical trials of heart failure: the quality of life and economic components of EPHESUS (EPlerenone's neuroHormonal Efficacy and SUrvival Study). Am Heart J 2002;143:636-642.

29. Pfeffer MA, Swedberg K, Granger CB, Held P, McMurray JJV, Michelson EL, Olofsson B, Östergren J, Yusuf S; CHARM investigators and committees. Effects of candesartan on mortality and morbidity in patients with chronic heart failure: the CHARM-Overall programme. Lancet 2003;362:759-766.

30. Oler A, Whooley MA, Oler J, Grady D. Adding heparin to aspirin reduces the incidence of myocardial infarction and death in patients with unstable angina: a meta-analysis. JAMA 1996;276:811-815.

31. CAPRIE Steering Committee. A randomised, blinded, trial of clopidogrel versus aspirin in patients at risk of ischaemic events (CAPRIE). Lancet 1996;348:1329-1339.

32. Yusuf S, Zhao F, Mehta SR, Chrolavicius S, Tognoni G, Fox KK. Effects of clopidogrel in addition to aspirin in patients with acute coronary syndromes without ST-segment elevation. N Engl J Med 2001;345:494-502.

33. Mehta SR, Yusuf S, Peters RJG, Bertrand ME, Lewis BS, Natarajan MK, Malmberg K, Rupprecht H-J, Zhao F, Chrolaviclus S, Copland I, Fox KAA; Clopidogrel in Unstable angina to prevent Recurrent Events trial (CURE) investigators. Effects of pretreatment with clopidogrel and aspirin followed by long-term therapy in patients undergoing percutaneous coronary intervention: the PCI-CURE study. Lancet 2001;358:527-533.

34. Steinhubl SR, Berger PB, Mann JT III, Fry ETA, DeLago A, Wilmer C, Topol EJ; CREDO investigators. Early and sustained dual oral antiplatelet therapy following percutaneous coronary intervention. A randomized controlled trial. JAMA 2002;288:2411-2420.

35. Antman EM, Cohen M, Radley D, McCabe C, Rush J, Premmereur J, Braunwald E. Assessment of the treatment effect of enoxaparin for unstable angina/non-Q-wave myocardial infarction. TIMI 11B-ESSENCE meta-analysis. Circulation 1999;100:1602-1608.

36. The Direct Thrombin Inhibitor Trialists' Collaborative Group. Direct thrombin inhibitors in acute coronary syndromes: principal results of a metaanalysis based on individual patients' data. Lancet 2002;359:294-302.

37. Rahimtoola SH. Coronary bypass surgery for chronic angina-1981. A perspective. Circulation 1982;65:225-241.

38. Pagley PR, Beller GA, Watson DD, Gimple LW, Ragosta M. Improved 
outcome after coronary bypass surgery in patients with ischemic cardiomyopathy and residual myocardial viability. Circulation 1997;96:793-800.

39. Allman KC, Shaw LJ, Hachamovitch R, Udelson JE. Myocardial viability testing and impact of revascularization on prognosis in patients with coronary artery disease and left ventricular dysfunction: a meta-analysis. J Am Coll Cardiol 2002;39:1151-1158.

40. Hachamovitch R, Berman DS, Kiat H, Cohen I, Lewin H, Amanullah A, Kang X, Friedman J, Diamond GA. Incremental prognostic value of adenosine stress myocardial perfusion single-photon emission computed tomography and impact on subsequent management in patients with or suspected of having myocardial ischemia. Am J Cardiol 1997;80:426-433.

41. Dakik HA, Howell JF, Lawrie GM, Espada R, Weilbaecher DG, He Z-X, Mahmarian JJ, Verani MS. Assessment of myocardial viability with $99 \mathrm{~m}$ Tc-sestamibi tomography before coronary bypass graft surgery: correlation with histopathology and postoperative improvement in cardiac function. Circulation 1997;96:2892-2898.

42. Haas F, Haehnel CJ, Picker W, Nekolla S, Martinoff S, Meisner H, Schwaiger M. Preoperative positron emission tomographic viability assessment and perioperative and postoperative risk in patients with advanced ischemic heart disease. J Am Coll Cardiol 1997;30:1693-1700.

43. Galassi AR, Tamburino C, Grassi R, Foti R, Mammana C, Virgilio A, Licciardello G, Musumeci S, Giuffrida G. Comparison of technetium 99mtetrofosmin and thallium-201 single photon emission computed tomographic imaging for the assessment of viable myocardium in patients with left ventricular dysfunction. J Nucl Cardiol 1998;5:56-53.

44. Iskander S, Iskandrian AE. Risk assessment using single-photon emission computed tomographic technetium-99m sestamibi imaging. J Am Coll Cardiol 1998;32:57-62.

45. Amanullah AM, Berman DS, Erel J, Kiat H, Cohen I, Germano G, Friedman JD, Hachamovitch R. Incremental prognostic value of adenosine myocardial perfusion single-photon emission computed tomography in women with suspected coronary artery disease. Am J Cardiol 1998;82:725-730.

46. Meluzin J, Cerny J, Frelich M, Stetka F, Spinarova L, Popelova J, Stipal R. Prognostic value of the amount of dysfunctional but viable myocardium in revascularized patients with coronary artery disease and left ventricular dysfunction. Investigators of this Multicenter Study. J Am Coll Cardiol 1998;32:912-920.

47. Baumgartner H, Porenta G, Lau Y-K, Wutte M, Klaar U, Mehrabi M, Siegel RJ, Czernin J, Laufer G, Sochor H, Schelbert H, Fishbein MC, Maurer G. Assessment of myocardial viability by dobutamine echocardiography, positron emission tomography and thallium-201 SPECT. Correlation with histopathology in explanted hearts. J Am Coll Cardiol 1998;32:1701-1708.

48. Kim RJ, Wu E, Rafael A, Chen E-L, Parker MA, Simonetti O, Klocke FJ, Bonow RO, Judd RM. The use of contrast-enhanced magnetic resonance imaging to identify reversible myocardial dysfunction. N Engl J Med 2000;343: 1445-1453.

49. Sharir T, Bacher-Stier C, Dhar S, Lewin HC, Miranda R, Friedman JD, Germano G, Berman DS. Identification of severe and extensive coronary artery disease by postexercise regional wall motion abnormalities in Tc-99m sestamibi gated single-photon emission computed tomography. Am J Cardiol 2000;86:1171-1175.

50. Siebelink H-MJ, Blanksma PK, Crijns HJGM, Bax JJ, van Boven AJ, Kingma T, Piers DA, Pruim J, Jager PL, Vaalburg W, van der Wall EE. No difference in cardiac event-free survival between positron emission tomography-guided and single-photon emission computed tomography-guided patient management. A prospective, randomized comparison of patients with suspicion of jeopardized myocardium. J Am Coll Cardiol 2001;37:81-88.

51. Galassi AR, Azzarelli S, Tomaselli A, Giosofatto R, Ragusa A, Musumeci $S$, Tamburino C, Giuffrida G. Incremental prognostic value of technetium$99 \mathrm{~m}$-tetrofosmin exercise myocardial perfusion imaging for predicting outcomes in patients with suspected or known coronary artery disease. Am J Cardiol 2001;88:101-106.

52. Calnon DA, McGrath PD, Doss AL, Harrell FE Jr, Watson DD, Beller GA. Prognostic value of dobutamine stress technetium-99m-sestamibi singlephoton emission computed tomography myocardial perfusion imaging: stratification of a high-risk population. J Am Coll Cardiol 2001;38:1511-1517.

53. Hachamovitch R, Berman DS, Kiat H, Cohen I, Friedman JD, Shaw LJ. Value of stress myocardial perfusion single photon emission computed tomography in patients with normal resting electrocardiograms. An evaluation of incremental prognostic value and cost-effectiveness. Circulation 2002;105:823-829.
54. Gibson PB, Demus D, Noto R, Hudson W, Johnson LL. Low event rate for stress-only perfusion imaging in patients evaluated for chest pain. J Am Coll Cardiol 2002;39:999-1004.

55. Giri S, Shaw LJ, Murthy DR, Travin MI, Miller DD, Hachamovitch R, Borges-Neto S, Berman DS, Waters DD, Heller GV. Impact of diabetes on the risk stratification using stress single-photon emission computed tomography myocardial perfusion imaging in patients with symptoms suggestive of coronary artery disease. Circulation 2002;105:32-40.

56. Klein C, Nekolla SG, Bengel FM, Momose M, Sammer A, Haas F, Schnackenburg B, Delius W, Mudra H, Wolfram D, Schwaiger M. Assessment of myocardial viability with contrast-enhanced magnetic resonance imaging. Comparison with positron emission tomography. Circulation 2002;105:162-167.

57. Bello D, Shah DJ, Farah GM, Di Luzio S, Parker M, Johnson MR, Cotts WG, Klocke FJ, Bonow RO, Judd RM, Gheorghiade M, Kim RJ. Gadolinium cardiovascular magnetic resonance predicts reversible myocardial dysfunction and remodeling in patients with heart failure undergoing beta-blocker therapy. Circulation 2003;108:1945-1953.

58. Berman DS, Kang X, Hayes SW, Friedman JD, Cohen I, Abidov A, Shaw LJ, Amanullah AM, Germano G, Hachamovitch R. Adenosine myocardial perfusion single-photon emission computed tomography in women compared with men. Impact of diabetes mellitus on incremental prognostic value and effect on patient management. J Am Coll Cardiol 2003;41:1125-1133.

59. Bax JJ, Schinkel AFL, Boersma E, Rizzello V, Elhendy A, Maat A, Roelandt JRTC, van der Wall EE, Poldermans D. Early versus delayed revascularization in patients with ischemic cardiomyopathy and substantial viability: impact on outcome. Circulation 2003;108(Suppl 1):39-42.

60. Abidov A, Bax JJ, Hayes SW, Hachamovitch R, Cohen I, Gerlach J, Kang X, Friedman JD, Germano G, Berman DS. Transient ischemic dilation ratio of the left ventricle is a significant predictor of future cardiac events in patients with otherwise normal myocardial perfusion SPECT. J Am Coll Cardiol 2003;42:1818-1825.

61. Georghiade M, Bonow RO. Chronic heart failure in the United States. A manifestation of coronary artery disease. Circulation 1998;97:282-289.

62. Armstrong PW, Moe GW. Medical advances in the treatment of congestive heart failure. Circulation 1993;88:2941-2952.

63. Garg R, Yusuf S. Overview of randomized trials of angiotensin-converting enzyme inhibitors on mortality and morbidity in patients with heart failure. JAMA 1995;273:1450-1456.

64. Hunt SA, Baker DW, Chin MH, Cinquegrani MP, Feldman AM, Francis GS, Ganiats TG, Goldstein S, Gregoratos G, Jessup ML, Nobel RJ, Packer M, Silver MA, Stevenson LW, committee members. Gibbons RJ, Antman EM, Alpert JS, Faxon DP, Fuster V, Gregoratos G, Jacobs AK, Hiratzka LF, Russell RO, Smith SC Jr, task force members. ACC/AHA guidelines for the evaluation and management of chronic heart failure in the adult: executive summary. A report of the American College of Cardiology/American Heart Association Task Force on Practice Guidelines (committee to revise the 1995 guidelines for the evaluation and management of heart failure). Developed in collaboration with the International Society for Heart and Lung Transplantation. Endorsed by the Heart Failure Society of America. J Am Coll Cardiol 2001;38:2101-2113.

65. Cohn JN, Tognoni G; Valsartan Heart Failure trial investigators. A randomized trial of the angiotensin-receptor blocker valsartan in chronic heart failure. N Engl J Med 2001;345:1667-1675.

66. Pitt B, Zannad F, Remme WJ, Cody R, Castaigne A, Perez A, Palensky J, Wittes J; Randomized Aldactone Evaluation Study investigators. The effect of spironolactone on morbidity and mortality in patients with severe heart failure. N Engl J Med 1999;341:709-717.

67. Pitt B, Remme W, Zannad F, Neaton J, Martinez F, Roniker B, Bittman R, Hurley S, Kleiman J, Gatlin M; Eplerenone Post-Acute Myocardial Infarction Heart Failure Efficacy and Survival study investigators. Eplerenone, a selective aldosterone blocker, in patients with left ventricular dysfunction after myocardial infarction. N Engl J Med 2003;348:1309-1321.

68. Garg R, Gorlin R, Smith T, Yusuf S; Digitalis Investigation Group. The effect of digoxin on mortality and morbidity in patients with heart failure. N Engl J Med 1997;336:525-533.

69. Hall SA, Cigarroa CG, Marcoux L, Risser RC, Grayburn PA, Eichhorn EJ. Time course of improvement in left ventricular function, mass and geometry in patients with congestive heart failure treated with beta-adrenergic blockade. J Am Coll Cardiol 1995;25:1154-1161.

70. Bristow MR, Gilbert EM, Abraham WT, Adams KF, Fowler MB, Hershberger 
RE, Kubo SH, Narahara KA, Ingersoll H, Krueger S, Young S, Shusterman $\mathrm{M} ; \mathrm{MOCHA}$ investigators. Carvedilol produces dose-related improvements in left ventricular function and survival in subjects with chronic heart failure. Circulation 1996;94:2807-2816.

71. Poole-Wilson PA, Swedberg K, Cleland GF, Di Lenarda A, Hanrath P, Komajda M, Lubsen J, Lutiger B, Metra M, Remme WJ, Torp-Pedersen C, Scherhag A, Skene A; COMET investigators. Comparison of carvedilol and metoprolol on clinical outcomes in patients with chronic heart failure in the Carvedilol Or Metoprolol European Trial (COMET): a randomised controlled trial. Lancet 2003;362:7-13.

72. Moss AJ, Zareba W, Hall WJ, Klein H, Wilber DJ, Cannom DS, Daubert JP, Higgins SL, Brown MW, Andrews ML; Multicenter Automatic Defibrillator Implantation Trial II investigators. Prophylactic implantation of a defibrillator in patients with myocardial infarction and reduced ejection fraction. N Engl J Med 2002;346:877-883.

73. Stevenson WG, Stevenson LW, Middlekauff HR, Saxon LA. Sudden death prevention in patients with advanced ventricular dysfunction. Circulation 1993;88:2953-2961.

74. Felker GM, Thompson RE, Hare JM, Hruban RH, Clemetson DE, Howard DL, Baughman KL, Kasper EK. Underlying causes and long-term survival in patients with initially unexplained cardiomyopathy. N Engl J Med 2000;342: 1077-1084.

75. Uretsky BF, Thygesen K, Armstrong PW, Cleland JG, Horowitz JD, Massie BM, Packer M, Poole-Wilson PA, Ryden L. Acute coronary findings at autopsy in heart failure patients with sudden death. Results from the Assessment of Treatment with Lisinopril And Survival (ATLAS) Trial. Circulation 2000;102:611-616.

76. Mann DL. Mechanisms and models in heart failure. A combinatorial approach. Circulation 1999;100:999-1008.

77. Bonow RO. The hibernating myocardium: implications for management of congestive heart failure. Am J Cardiol 1995;75:17A-25A.

78. Pu M, Thomas JD, Gillinov MA, Griffin BP, Brunken RC. Importance of ischemic and viable myocardium for patients with chronic ischemic mitral regurgitation and left ventricular dysfunction. Am J Cardiol 2003;92: 862-864.

79. Redfield MM, Jacobsen SJ, Burnett JC Jr, Mahoney DW, Bailey KR, Rodeheffer RJ. Burden of systolic and diastolic ventricular dysfunction in the community: appreciating the scope of the heart failure epidemic. JAMA 2003;289:194-202.

80. Tsang TSM, Gersh BJ, Appleton CP, Tajik AJ, Barnes ME, Bailey KR, Oh JK, Leibson C, Montgomery SC, Seward JB. Left ventricular diastolic dysfunction as a predictor of the first diagnosed nonvalvular atrial fibrillation in 840 elderly men and women. J Am Coll Cardiol 2002;40:1636-1644.

81. Benjamin EJ, Wolf PA, D'Agostino RB, Silbershatz H, Kannel WB, Levy D. Impact of atrial fibrillation on the risk of death. The Framingham Heart Study. Circulation 1998;98:946-952.

82. Fuster V, Rydén LE, Asinger RW, Cannom DS, Crijns HJ, Frye RL, Halperin JL, Kay GN, Klein WW, Lévy S, McNamara RL, Prystowsky EN, Wann LS, Wyse DG, Writing Committee Members. Task Force Report. ACC/AHA/ ESC guidelines for the management of patients with atrial fibrillation. A report of the American College of Cardiology/American Heart Association Task Force on Practice Guidelines and the European Society of Cardiology Committee for Practice Guidelines and Policy Conferences (committee to develop guidelines for the management of patients with atrial fibrillation) developed in collaboration with the North American Society of Pacing and Electrophysiology. Eur Heart J 2001;22:1852-1923.

83. Kirchhof P, Eckardt L, Loh P, Weber K, Fischer R-J, Seidl K-H, Böcker D, Breithardt G, Haverkamp W, Borggrefe M. Anterior-posterior versus anterior-lateral electrode positions for external cardioversion of atrial fibrillation: a randomised trial. Lancet 2002;360:1275-1279.

84. The Atrial Fibrillation Follow-up Investigation of Rhythm Management (AFFIRM) investigators. Baseline characteristics of patients with atrial fibrillation: the AFFIRM Study. Am Heart J 2002;143:991-1001.

85. Van Gelder IC, Hagens VE, Bosker HA, Kingma JH, Kamp O, Kingma T, Said SA, Darmanata JI, Timmermans AJM, Tijssen JGP, Crijns HJGM; Rate Control Versus Electrical Cardioversion for Persistent Atrial Fibrillation Study Group. A comparison of rate control and rhythm control in patients with recurrent persistent atrial fibrillation. N Engl J Med 2002;347:1834-1840.

86. Pappone C, Oreto G, Rosanio S, Vicedomini G, Tocchi M, Gugliotta F, Salvati A, Dicandia C, Calabrò MP, Mazzone P, Ficarra E, Di Gioia C, Gul- letta S, Nardi S, Santinelli V, Benussi S, Alfieri O. Atrial electroanatomic remodeling after circumferential radiofrequency pulmonary vein ablation. Efficacy of an anatomic approach in a large cohort of patients with atrial fibrillation. Circulation 2001;104:2539-2544.

87. Oral H, Knight BP, Tada H, Özaydin M, Chugh A, Hassan S, Scharf C, Lai SWK, Greenstein R, Pelosi F Jr, Strickberger A, Morady F. Pulmonary vein isolation for paroxysmal and persistent atrial fibrillation. Circulation 2002;105:1077-1081.

88. Pappone C, Rosanio S, Augello G, Gallus G, Vicedomini G, Mazzone P, Gulletta S, Gugliotta F, Pappone A, Santinelli V, Tortoriello V, Sala S, Zangrillo A, Crescenzi G, Benussi S, Alfieri O. Mortality, morbidity, and quality of life after circumferential pulmonary vein ablation for atrial fibrillation. Outcomes from a controlled nonrandomized long-term study. J Am Coll Cardiol 2003;42:185-197.

89. Petersen P, Grind M, Adler J; SPORTIF II investigators. Ximelagatran versus warfarin for stroke prevention in patients with nonvalvular atrial fibrillation. SPORTIF II: a dose-guiding, tolerability, and safety study. J Am Coll Cardiol 2003;41:1445-1451.

90. Executive Steering Committee on behalf of the SPORTIF III Investigators. Stroke prevention with the oral direct thrombin inhibitor ximelagatran compared with warfarin in patients with non-valvular atrial fibrillation (SPORTIF III): randomised controlled trial. Lancet 2003;362:1691-1698.

91. Zipes DP, Wellens HJJ. Sudden cardiac death. Circulation 1998;98:23342351.

92. Zheng Z-J, Croft JB, Giles WH, Mensah GA. Sudden cardiac death in the United States, 1989 to 1998. Circulation 2001;104:2158-2163.

93. Moss AJ, Hall WJ, Cannom DS, Daubert JP, Higgins SL, Klein H, Levine JH, Saksena S, Waldo AL, Wilber D, Brown MW, Heo M; Multicenter Automatic Defibrillator Implantation Trial investigators. Improved survival with an implanted defibrillator in patients with coronary disease at high risk for ventricular arrhythmia. N Engl J Med 1996;335:1933-1940.

94. Buxton AE, Lee KL, Fisher JD, Josephson ME, Prystowsky EN, Hafley G; Multicenter Unsustained Tachycardia Trial investigators. A randomized study of the prevention of sudden death in patients with coronary artery disease. N Engl J Med 1999;341:1882-1890.

95. Lee KL, Hafley G, Fisher JD, Gold MR, Prystowsky EN, Talajic M, Josephson ME, Packer DL, Buxton AE; Multicenter Unsustained Tachycardia Trial investigators. Effect of implantable defibrillators on arrhythmic events and mortality in the Multicenter Unsustained Tachycardia Trial. Circulation 2002;106:233-238.

96. Bänsch D, Antz M, Boczor S, Volkmer M, Tebbenjohanns J, Seidl K, Block M, Gietzen F, Berger J, Kuck KH; CAT investigators. Primary prevention of sudden cardiac death in idiopathic dilated cardiomyopathy. The Cardiomyopathy Trial (CAT). Circulation 2002;105:1453-1458.

97. Nieto FJ, Young TB, Lind BK, Shahar E, Samet JM, Redline S, D'Agostino RB, Newman AB, Lebowitz MD, Pickering TG; Sleep Heart Health Study. Association of sleep-disordered breathing, sleep apnea, and hypertension in a large community-based study. JAMA 2000;283:1829-1836.

98. Peppard PE, Young T, Palta M, Skatrud J. Prospective study of the association between sleep-disordered breathing and hypertension. N Engl J Med 2000;342:1378-1384.

99. Shamsuzzaman ASM, Winnicki M, Lanfranchi P, Wolk R, Kara T, Accurso $\mathrm{V}$, Somers VK. Elevated C-reactive protein in patients with obstructive sleep apnea. Circulation 2002;105:2462-2464.

100. Javaheri S, Parker TJ, Liming JD, Corbett WS, Nishiyama H, Wexler L, Roselle GA. Sleep apnea in 81 ambulatory male patients with stable heart failure. Types and their prevalences, consequences, and presentations. Circulation 1998;97:2154-2159.

101. Khan NE, De Souza A, Mister R, Flather M, Clague J, Davies S, Collins P, Wang D, Sigwart U, Pepper J. A randomized comparison of off-pump and on-pump multivessel coronary-artery bypass surgery. N Engl J Med 2004;350: $21-28$.

102. Thourani VH, Weintraub WS, Guyton RA, Jones EL, Williams WH, Elkabbani S, Craver JM. Outcomes and long-term survival for patients undergoing mitral valve repair versus replacement. Effect of age and concomitant coronary artery bypass grafting. Circulation 2003;108:298-304.

103. Enriquez-Sarano M, Schaff HV, Frye RL. Mitral regurgitation: what causes the leakage is fundamental to the outcome of valve repair. Circulation 2003;108:253-256. 